\title{
THE INFLUENCE OF ADDITION OF DRIED TOMATO POMACE ON THE PHYSICAL AND SENSORY PROPERTIES OF WHOLE GRAIN RYE FLOUR COOKIES
}

\author{
Jelena M. Tomić ${ }^{1}$, Miona M. Belović ${ }^{1}$, Aleksandra M. Torbica ${ }^{1}$, Biljana S. Pajin², \\ Ivana S. Lončarević ${ }^{2}$ Jovana S. Petrović ${ }^{2}$, Aleksandar Z. Fišteš ${ }^{2}$ \\ ${ }^{1}$ University of Novi Sad, Institute of Food Technology, Bulevar cara Lazara 1, 21000 Novi Sad, Serbia \\ ${ }^{2}$ University of Novi Sad, Faculty of Technology, Bulevar cara Lazara 1, 21000 Novi Sad, Serbia
}

\author{
*Corresponding author: \\ Phone: +381214853780 \\ Fax: +38121450725 \\ E-mail address: jelena.tomic@fins.uns.ac.rs
}

\begin{abstract}
One of the potential raw materials which could be used for production of food with added nutritional value is tomato pomace, a by-product from tomato processing. On the other hand, requirements of consumers for diverse food with potential for health benefits impose the need for creation of products made from different cereals. In this respect, the aim of this study was to evaluate the influence of addition of dried tomato pomace on the physical and sensory properties of whole grain rye flour cookies. The whole grain rye flour was substituted with tomato pomace powder in two levels $(15 \%$ and $25 \%)$ in the standard formulation of short-dough cookie. The quality of final products was evaluated by instrumental and sensory methods. The results clearly demonstrated that redness $\left(+a^{*}\right)$ and yellowness $\left(+b^{*}\right)$ were highly influenced by level of tomato pomace in the cookie formulations due to its content of carotenoid pigments. The spread factor of the cookies made with addition of tomato pomace powder was higher than the control sample. Hardness of the cookie samples decreased for approximately $50 \%$ for the cookie sample with $25 \%$ tomato pomace level substitution when compared with control sample. According to the results of sensory analysis, substitution level of $15 \%$ caused decrease of surface roughness, fracturability, and granularity, as well as increase of caramel flavour intensity. Substitution level of $25 \%$ caused higher degree of cookie softening and more pronounced tomato flavour.
\end{abstract}

Key words: tomato pomace, whole grain rye flour, cookies, texture, sensory analysis

\section{INTRODUCTION}

Tomato pomace, a by-product of industrial processing of tomato, comprise about 4$7 \%(\mathrm{w} / \mathrm{w})$ of the total tomato processed into tomato products (Del Valle et al., 2006; Kalogeropoulos et al., 2012). Tomato pomace consists mostly of skin, seeds, and vascular tissue, containing up to $60 \%$ of dietary fibre per dry weight (AlWandawi et al., 1985; Del Valle et al., 2006; Lenucci et al., 2013). By-product of tomato processing is characterized by the high moisture content (about $80 \%$ ), which makes it susceptible to microbiological contamination (Al-Wandawi et al., 1985; Lenucci et al., 2013). Drying process (convection or freeze drying) has been shown to be the most favourable pre-treatment for the preservation of fruit and vegetable processing industry by-products (O'Shea et al., 2012). Tomato pomace also represents a source of bioactive phytochemicals, such as lycopene, $\beta$-carotene and phenolic compounds, predominantly hydroxycinnamic acids and flavonols (Chanforan et al., 2012; Kalogeropoulos et al., 2012). 
The insoluble-soluble fibre ratio in tomato pomace is $10: 1$, which makes these fibres more similar to those originating from cereals (García Herrera et al., 2010). In addition, tomato pomace proteins are rich in lysine, making it suitable for fortification of low-lysine foods, such as those based on cereals (Bajerska et al., 2015).

Previous studies that dealt with the enrichment of cereal based product with tomato pomace have included the enrichment of wheat bread (Majzoobi et al., 2011; Nour et al., 2015), rye bread (Bajerska et al., 2015), snack foods produced from extruded barley (Altan et al., 2008) and extruded durum wheat (Yağcı and Göğüş, 2008).

Increasing demands for the diverse foods with health benefits led to the use of different cereals in the production of baking and confectionary products. These raw materials present a challenge for processing due to the fact that the proteins they contain are not of the same type and quality as those of wheat.

Among these cereals, rye is commonly used for bread and ginger cookie production even though rye proteins are not capable of forming such continuous protein networks as wheat proteins can. Pentosans have the most prominent technological role in rye dough processing while dietary fibre and phenolic compounds contribute to the nutritional value of products (Hansen et al., 2002; BondiaPons et al., 2009).

Furthermore, changes in rheological properties of rye dough have been associated with a decrease in water-holding properties of the dietary fibre (Hansen et al., 2002). Therefore, it was considered that water holding capacity of rye cookie dough could be improved by an addition of dried tomato pomace, which was previously shown to possess good water retention capacity (Belović et al., 2016).

Bearing in mind all mentioned above, the aim of this study was to examine the influence of the dried tomato pomace addition on the physical and sensory properties of whole grain rye flour cookies.

\section{MATERIALS AND METHODS}

\author{
Material and proximate composition \\ analysis
}

In this study, whole grain rye flour (WGRF) purchased from the local supermarket was used as raw material for the cookies production. Tomato pomace prepared from local tomato variety was lyophilized in an industrial scale freeze-drier for 36 hours. Initial and final temperature of the material was $-30{ }^{\circ} \mathrm{C}$ and $+37{ }^{\circ} \mathrm{C}$, respectively, while the pressure in the chamber varied from $5 \times 10^{-2}$ to $7 \times 10^{-3} \mathrm{mbar}$ during lyophilisation. Lyophilized tomato pomace was ground in a coffee grinder (Gorenje, Velenje, Slovenia) in order to obtain a powder with particle diameter $<150 \mu \mathrm{m}$, as determined by a rotational sieving machine (Bühler, Uzwil, Switzerland). Moisture, ash, sugars, starch, protein, fat, and dietary fibre content of whole grain rye flour (WGRF) and tomato pomace powder (TPP) were determined according to the standard methods (AOAC 2000).

\section{Swelling coefficient and water retention capacity (WRC)}

Swelling coefficient and water retention capacity (WRC) of whole grain rye flour tomato pomace blends were determined using the methods described by Robertson et al. (2000) with some modifications. For the purpose of swelling coefficient and WRC determination, $3 \mathrm{~g}$ of rye flour - tomato pomace blends, placed in a closed centrifuge tube, were hydrated in $30 \mathrm{~mL}$ of distilled water at room temperature. Whole grain rye flour was used as a control sample. The bed volume occupied by the sample was recorded after equilibration (18 h). Swelling coefficient (SC) was calculated using the following equation:

$\mathrm{SC}(\mathrm{mL} / \mathrm{g})=\frac{\text { Volume occupied by the sample }}{\text { Original sample dry weight }}$

After equilibration time (18 $\mathrm{h})$, the samples were centrifuged $(3,000 \mathrm{~g} ; 20 \mathrm{~min})$ (Eppendorf Centrifuge $5804 \mathrm{R}$, Hamburg, Germany). The supernatant was decanted and the solid residue was weighed. WRC 
was calculated using the following equation:

WRC $(\mathrm{g} / \mathrm{g})=\frac{\text { Wet residue weight-Powder weight }}{\text { Powder weight }}$

\section{Preparation of cookies}

The cookie dough was prepared according to the following formula: whole grain rye flour/blends of whole grain rye flour and tomato pomace powder $(99.7 \mathrm{~g})$, sugar powder $(34.9 \mathrm{~g})$, vegetable fat $(20.9 \mathrm{~g})$, sodium chloride $(0.5 \mathrm{~g})$, sodium bicarbonate $(0.3 \mathrm{~g})$, ammonium bicarbonate $(0.2 \mathrm{~g})$ and water (Pajin, 2009). Tomato pomace powder was used to replace part of the whole grain rye flour (15\% and $25 \%)$ in applied cookie recipe. For cookie formulation with whole grain rye flour, water was added in order to achieve $18 \%$ of dough moisture. In the case of formulations with tomato pomace substitution, the content of added water was calculated on the basis of WRC of the blends. WGRF/blends, fat, and powdered sugar were firstly mixed thoroughly for $5.5 \mathrm{~min}$. The remaining raw materials dissolved in distilled water were added and it was mixed for another 15 minutes. After resting (3 hours at $20{ }^{\circ} \mathrm{C}$, in thermostat), the dough was sheeted on a Laminoir Marchand LA4-500 to a uniform thickness of about $6 \mathrm{~mm}$. The cookies were round shaped with a cutter of $45 \mathrm{~mm}$ diameter and baked on an aluminium tray at $230{ }^{\circ} \mathrm{C}$ for 8.5-12.5 min. The cookie samples were then cooled down at room temperature for at least 30 min on the baking tray and finally packed into aluminium foiled pouches.

\section{Colour, texture and spread factor of cookies}

The colour of cookies was measured by a Chroma Meter CR-400 (Konica Minolta, Japan) on the top and bottom of the cookie surface. CIE L* (lightness), CIE $a^{*}$ $\left(+a^{*}=\right.$ redness, $-a^{*}=$ greenness $)$, and CIE $b^{*}\left(+b^{*}=\right.$ yellowness, $-b^{*}=$ blueness $)$ were read using a $D_{65}$ light source and the observer angle of $2^{\circ}$. The tristimulus values of CIE L*a* $b^{*}$ readings were calibrated against a standard white plate $(Y=84.8$; $x=0.3199 ; y=0.3377$ ). Colour readings in the centre of twelve cookies per batch were recorded, and the results were averaged. Textural analysis of cookies was conducted by using a TA.XTPlus Texture Analyzer (Stable Micro Systems, England, UK), equipped with a 3-point bending rig (HDP/3PB), and a $30 \mathrm{~kg}$ load cell. The test distance between the supports was $20 \mathrm{~mm}$. Texture analyser settings were: mode - measure force in compression; pre-test speed $-1.0 \mathrm{~mm} / \mathrm{s}$; test speed $-3.0 \mathrm{~mm} / \mathrm{s}$; post-test speed $10.0 \mathrm{~mm} / \mathrm{s}$; distance - $10.0 \mathrm{~mm}$; trigger force $-50 \mathrm{~g}$. Five measurements per each batch sample were made.

The spread factor (SF) was determined from the ratio of width (W) and thickness ( $T$ ) of the cookie samples, according to the AACC methods (AACC, 1995). The average values of twelve determinations were reported.

All measurements were performed $1 \mathrm{~h}$ after baking, when cookies were cooled and stabilized. In addition, moisture content and texture were measured again after $24 \mathrm{~h}$ to get insight into changes during storage.

\section{Sensory analysis}

Six expert panellists from the Institute of Food Technology, aged 25-50 years, with sensory experience from sensory profiling work with different types of bakery and confectionery products, participated in the study. Panellists were initially provided with sensory terms of cookie sensory profiles used in previously published research (Pajin, 2009) but were told that they could keep, delete or add any terms as appropriate during the training sessions. A consensus approach was used to allow further discussion on each sample and to define the descriptors (Table 1). Once the descriptors were established, all samples were evaluated by the panel using an unstructured linear scale with the anchor points 0 - not perceptible and 100 strongly perceptible (Meilgaard, et al. 2000). The evaluation was performed in tasting booths with controlled environment conditions (ISO, 2007). The samples were coded with three-digit numbers and presented to the panellists. Drinking water was provided for palate cleansing after each sample testing. 
Table 1.

Sensory descriptors and their definitions

\begin{tabular}{|c|c|c|}
\hline Property & Descriptor & Definition \\
\hline \multirow{4}{*}{ Appearance } & Shape uniformity & Similarity between cookie and mould shape \\
\hline & Colour uniformity & Absence of differently coloured areas \\
\hline & & The amount of irregularity, bumps and cracks which can be seen \\
\hline & Surface roughness & $\begin{array}{l}\text { on the surface of the cookie; smoothness is the absence of } \\
\text { surface particles }\end{array}$ \\
\hline Odour & Intensity & Overall odour intensity \\
\hline \multirow{6}{*}{ Oral texture } & Hardness & Force required to bite through \\
\hline & Fracturability & The force with which the sample breaks in crumbles \\
\hline & Granularity & The perception of rough particles during consumption \\
\hline & Cohesiveness & The degree of sample deformation before it ruptures \\
\hline & Dissolving & The degree of cookie dissolving in mouth after the 4-6 chews \\
\hline & Moisture release & $\begin{array}{l}\text { Perception of water, measured by tactile means during } \\
\text { consumption }\end{array}$ \\
\hline \multicolumn{3}{|r|}{ 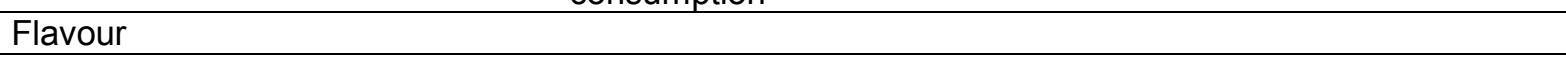 } \\
\hline \multirow{2}{*}{$\begin{array}{l}\text { Olfactory } \\
\text { sensations }\end{array}$} & Tomato & Aromatics or volatiles associated with tomato \\
\hline & Caramel & Aromatics or volatiles associated with caramelized sugar \\
\hline \multirow{3}{*}{$\begin{array}{l}\text { Taste } \\
\text { sensations }\end{array}$} & Sweet & $\begin{array}{l}\text { Basic taste produced by sugars such as sucrose, fructose, } \\
\text { glucose, etc. }\end{array}$ \\
\hline & Salty & $\begin{array}{l}\text { Basic taste produced by sodium salts, such as sodium chloride } \\
\text { and sodium glutamate, and in part by other salts, such as } \\
\text { potassium chloride }\end{array}$ \\
\hline & Bitter & $\begin{array}{l}\text { Basic taste produced by substances such as quinine, caffeine, } \\
\text { etc. }\end{array}$ \\
\hline
\end{tabular}

\section{RESULTS AND DISCUSSION}

The data of chemical properties of rye flour and tomato pomace are given in Table 2 calculated on the dry weight basis (dwb). The fibre and sugar content in the tomato pomace powder indicates a possible influence of these parameters on the physical and sensory characteristics of the final product, primarily in terms of the textural properties.

Also, the amount of dietary fibre, especially insoluble fibre present in tomato pomace makes this raw material a suitable ingredient for creation of confectionery products with increased nutritional value (García Herrera et al., 2010; NavarroGonzález et al., 2011).

The results presented in Table 3 clearly show that the addition of tomato pomace increased the swelling coefficient and water retention capacity as a result of the presence of a greater quantity of fibre provided by this raw material.

Regarding the colour measurements, the obtained results showed slight differences in the lightness values (Table 4). The increased levels of TPP substitution caused an increase in the colour coordinate values, such as redness and yellowness of the cookies, which can be also seen in Figure 1. This was expected due to the presence of red (lycopene) and orange ( $\beta$ carotene) carotenoid pigments in the added TPP (Chanforan et al., 2012).

There were differences among the tested samples in terms of moisture content, both after $1 \mathrm{~h}$ and $24 \mathrm{~h}$ (Table 4).

The increase of TPP content in the cookie formulations caused the higher levels of moisture content due to water binding properties of the used raw materials.

The spread factor of cookies made with tomato pomace powder was higher than the control sample (Table 4) due to dissolution of higher amount of sugars, which occurred during the baking process (Gavrilović, 2000). Substitution of $15 \%$ and $25 \%$ of WGRF with TPP increased the sugar content by $84 \%$ and $140 \%$, respectively. 
Table 2. Chemical composition of whole grain rye flour (WGRF) and tomato pomace powder (TPP)

\begin{tabular}{lcc}
\hline Parameter & Whole grain rye flour & Tomato pomace powder \\
\hline Moisture $(\%)$ & 10.37 & 3.05 \\
Ash $(\%$ dwb) & 1.53 & 1.51 \\
Total carbohydrates $(\%$ dwb) & 60.17 & 25.39 \\
Sugars $(\%$ dwb) & 3.85 & 25.39 \\
Dietary fibre $(\%$ dwb) & 12.94 & 62.04 \\
Cellulose $(\%$ dwb) & 3.84 & 13.46 \\
Total pectic substances $(\% d w b)$ & - & 4.66 \\
Protein $(\%$ dwb) & 12.39 & 3.53 \\
Fat $(\%$ dwb) & 2.32 & 0.79 \\
\hline
\end{tabular}

Data are presented as means of three replicates $(n=3)$.

Table 3. Swelling coefficient (SC) and water retention capacity (WRC) of whole grain rye flour (WGRF) and whole grain rye flour (WGRF) and tomato pomace powder (TPP) blends

\begin{tabular}{lccc}
\hline Parameter & WGRF & 85 WGRF:15 TPP & 75 WGRF:25 TPP \\
\hline Swelling coefficient $(\mathrm{SC})(\mathrm{mL} / \mathrm{g})$ & 3.31 & 4.32 & 5.25 \\
Water retention capacity $(\mathrm{WRC})(\mathrm{g} / \mathrm{g})$ & 1.11 & 1.31 & 1.43 \\
\hline
\end{tabular}
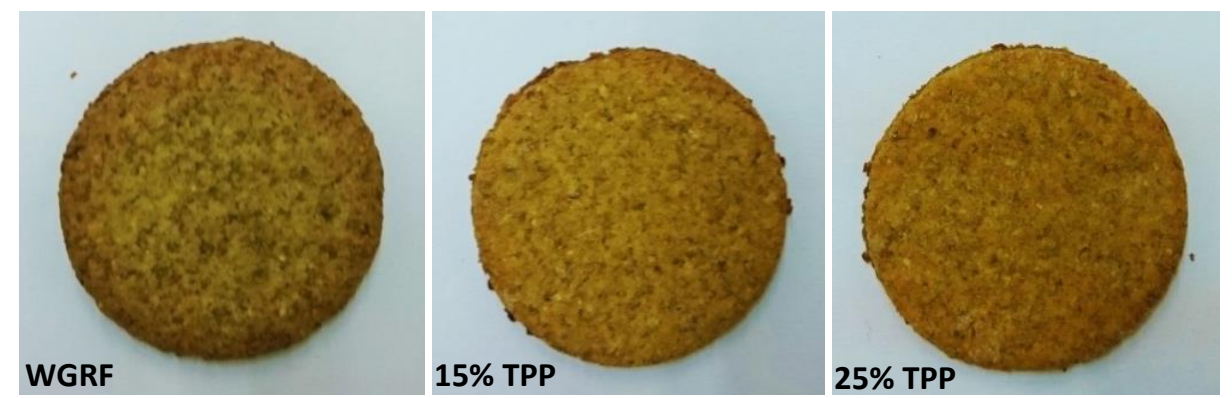

Figure 1. Cookies made of whole grain rye flour (WGRF) without and with tomato pomace powder (TPP) substitution (15\% and $25 \%)$

Table 4. Colour parameters, moisture values $1 \mathrm{~h}$ and $24 \mathrm{~h}$ after baking, and spread factor of the cookies

\begin{tabular}{lccc}
\hline Parameter & WGRF & 85 WGRF:15 TPP & 75 WGRF:25 TPP \\
\hline $\mathrm{L}^{*}$ & $56.94 \pm 0.86$ & $56.48 \pm 0.56$ & $55.37 \pm 0.86$ \\
$\mathrm{a}^{*}$ & $8.04 \pm 0.48$ & $11.27 \pm 0.39$ & $12.73 \pm 0.39$ \\
$\mathrm{~b}^{*}$ & $26.02 \pm 0.48$ & $35.23 \pm 0.63$ & $38.12 \pm 0.74$ \\
\hline Moisture after 1 $\mathrm{h}(\%)$ & $0.38 \pm 0.03$ & $5.72 \pm 0.12$ & $8.96 \pm 0.15$ \\
Moisture after 24 $\mathrm{h}(\%)$ & $0.85 \pm 0.05$ & $5.22 \pm 0.09$ & $8.38 \pm 0.07$ \\
\hline Spread factor $(\mathrm{W} / \mathrm{T})$ & $7.3 \pm 0.5$ & $9.3 \pm 0.3$ & $9.9 \pm 0.2$ \\
\hline
\end{tabular}

Measurement of cookies texture one hour after baking showed that the hardness value decreased when pomace content in the formulation was increased. However, the results of texture obtained $24 \mathrm{~h}$ after baking showed slightly different trends (Figure 2). Namely, the control sample, and the sample with 15\% TPP substitution showed increase of hardness, while the sample with $25 \%$ TPP substitution showed slight decrease. Figure 3 shows the results of the sensory evaluation of the cookies. It could be noticed that there were no differences among the all samples regar- ding the shape and colour uniformity. The rated surface roughness was decreased with increase in TPP level, which could be explained by the higher amount of reducing sugars (Manohar and Rao, 1997).

The greatest differences among samples were obtained for hardness, fracturability and granularity. Instrumental determination of hardness was in agreement with data obtained by sensory evaluation. The addition of TPP decreased the degree of cookie dissolving in mouth and sweet taste at the same time. 


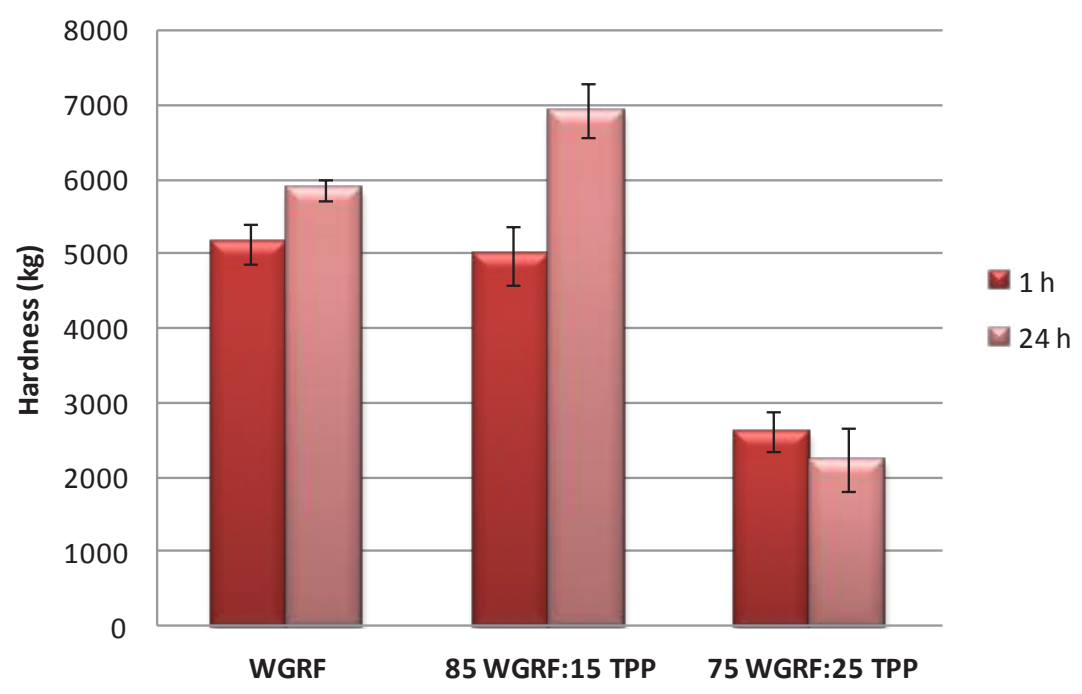

Figure 2. Hardness values of the cookie samples measured $1 \mathrm{~h}$ and $24 \mathrm{~h}$ after baking
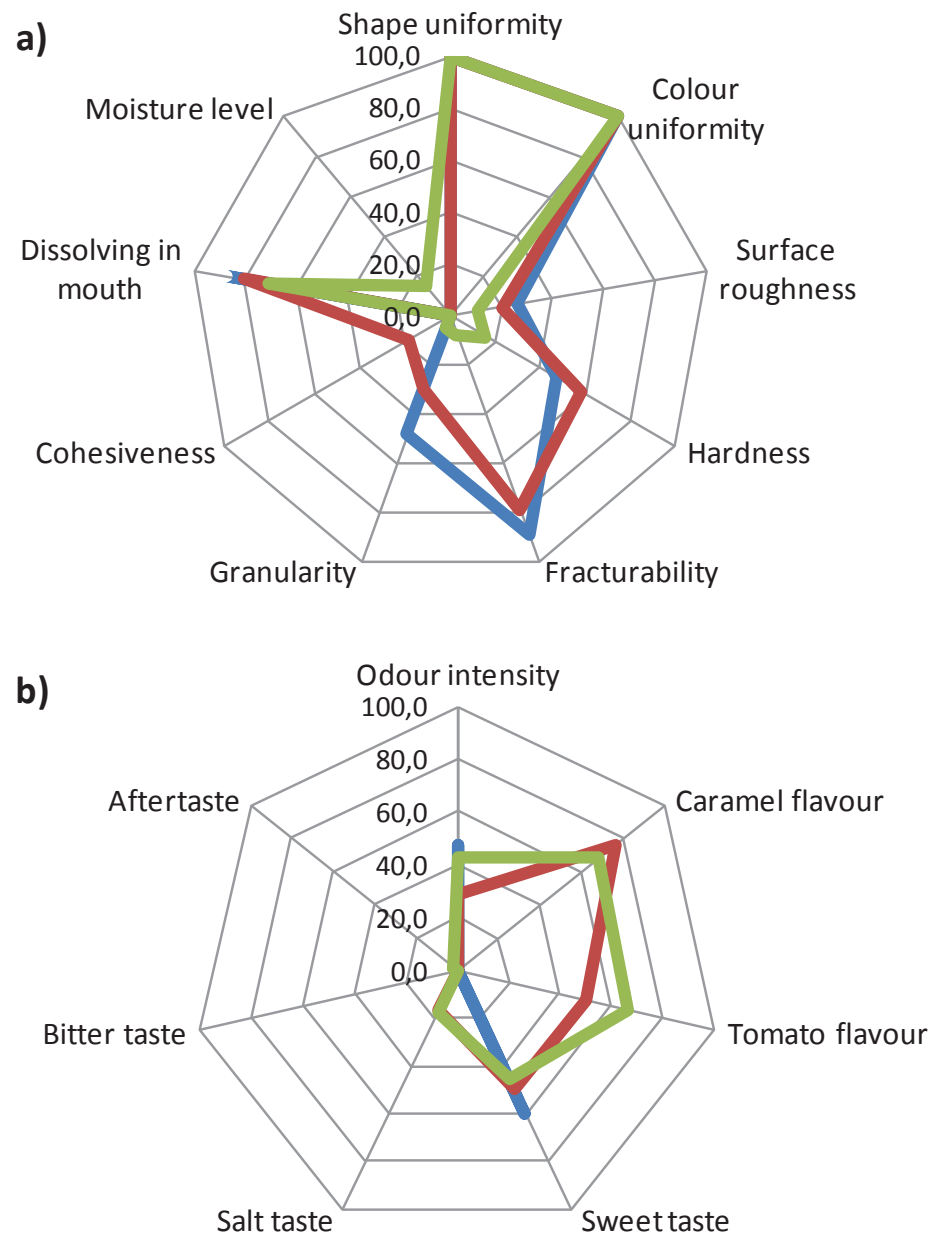

WGRF 2 WGRF:15 TPP 2 WGRF:25 TPP

Figure 3. Spider plots of the intensity of cookie samples' sensory properties; a) appearance and oral texture properties; b) odour and flavour properties 
By increasing the amount of tomato pomace, the intensity of tomato and caramel flavour increased, due to the aromatic taste characteristic for tomato pomace and caramelization of reducing sugars present in the raw material. In contrast to the expectations, the bitter taste was not perceived in all samples, although raw material contains higher amounts of tannins, which are known for its bitter taste (SotoVaca et al., 2012).

The cookies with tomato pomace substitution level of $15 \%$ had smoother surface and less granular texture, as well as improved fracturability and more pronounced caramel flavour in comparison with control cookies.

On the other hand, the cookies with tomato pomace substitution level of $25 \%$ were softer, with more pronounced tomato flavour when compared to both control cookies and cookies with $15 \%$ substitution level.

\section{CONCLUSIONS}

The obtained results indicate that the level of the tomato pomace powder incorporation changed various properties of the cookies, such us spread factor, hardness and colour of the cookie products. This study demonstrated the potential of using the studied tomato pomace portions in cookies production to achieve appropriate textural and sensory properties of the final product. According to the results of sensory analysis, substitution level of $15 \%$ caused decrease of surface roughness, fracturability, and granularity, as well as increase of caramel flavour intensity. Substitution level of $25 \%$ caused higher degree of cookie softening and more pronounced tomato flavour.

\section{ACKNOWLEDGEMENTS}

This paper is a result of the research within the project TR31007 financed by the Ministry of Education, Science and Technological Development, Republic of Serbia and the project 114-451-2085/2016 financed by the Provincial Secretariat for Science and Technological Development, Autonomous Province of Vojvodina, Republic of Serbia.

\section{REFERENCES}

1. AACC (1995). Approved Methods, American Association of Cereal Chemists St Paul, MN.

2. Altan, A., McCarthy, K.L., Maskana, M. (2008). Evaluation of snack foods from barley-tomato pomace blends by extrusion processing. Journal of Food Engineering, 84, 231-242.

3. Al-Wandawi, H., Abdul-Rahman, M. Al-Shaikhly, K. (1985). Tomato processing wastes as essential raw materials source. Journal of Agricultural and Food Chemistry, 33, 804-807.

4. AOAC International (2000). Official Methods of Analysis of Association of Official Analytical Chemists, $17^{\text {th }}$ Ed., Arlington, Virginia, USA.

5. Bajerska, J., Chmurzynska, A., Mildner-Szkudlarz, S., Drzymała-Czyż, S. (2015). Effect of rye bread enriched with tomato pomace on fat absorption and lipid metabolism in rats fed a highfat diet. Journal of the Science of Food and Agriculture, 95, 1918-1924.

6. Belović, M., Pajić-Lijaković, I., Torbica, A., Mastilović, J., Pećinar, I. (2016). The influence of concentration and temperature on the viscoelastic properties of tomato pomace dispersions. Food Hydrocolloids, 61, 617-624.

7. Bondia-Pons, I., Aura, A. M., Vuorela, S., Kolehmainen, M., Mykkänen, H., Poutanen, K. (2009). Rye phenolics in nutrition and health. Journal of Cereal Science, 49, 323-336.

8. Chanforan, C., Loonis, M., Mora, N., Caris-Veyrat, C., Dufour, C. (2012). The impact of industrial processing on health-beneficial tomato microconstituents. Food Chemistry, 134, 17861795.

9. Del Valle, M., Cámara, M., Torija, M. E. (2006). Chemical characterization of tomato pomace. Journal of the Science of Food and Agriculture, 86, 1232-1236.

10. García Herrera, P., Sánchez-Mata, M.C., Cámara, M. (2010). Nutritional characterization of tomato fiber as a useful ingredient for food industry. Innovative Food Science and Emerging Technologies, 11, 707-711.

11. Gavrilović, M. (2000) Tehnologija konditorskih proizvoda, Tehnološki fakultet, Novi Sad.

12. Hansen, H.B., Andreasen, M., Nielsen, M., Larsen, L., Knudsen, B.K., Meyer, A., Christensen, L.P., Hansen, A.. (2002). Changes in dietary fibre, phenolic acids and activity of endogenous enzymes during rye bread-making. European Food Research and Technology, 214, 33-42.

13. ISO (2007). Sensory analysis - general guidance for the design of test rooms, AMENDMENT 1. In ISO 8589. International Organization for Standardization, Geneva, Switzerland.

14. Kalogeropoulos, N., Chiou, A., Pyriochou, V., Peristeraki, A., Karathanos, V.T. (2012). Bioactive phytochemicals in industrial tomatoes and their processing byproducts. LWT - Food Science and Technology, 49, 213-216.

15. Lenucci, M.S., Durante, M., Anna, M., Dalessandro, G., Piro, G. (2013). Possible use of the carbohydrates present in tomato pomace and in 
byproducts of the supercritical carbon dioxide lycopene extraction process as biomass for bioethanol production. Journal of Agricultural and Food Chemistry, 61, 3683-3692.

16. Majzoobi, M., Ghavi, F.S., Farahnaky, A., Jamalian, J., Mesbahi, G. (2011). Effect of tomato pomace powder on the physicochemical properties of flat bread (Barbari bread). Journal of Food Processing and Preservation, 35, 247256.

17. Manohar, R.S., Rao, P.H. (1997). Effect of sugars on the rheological characteristics of biscuit dough and quality of biscuits. Journal of the Science of Food and Agriculture, 75, 383-390.

18. Meilgaard, M., Civille, G.V., Carr, B.T. (2000). Sensory Evaluation Techniques, $3^{\text {rd }}$ Ed., CRC Press, Boca Raton, FL, USA.

19. Navarro-González, I., García-Valverde, V., García-Alonso, H., Periago, M. J. (2011). Chemical profile, functional and antioxidant properties of tomato peel fiber. Food Research International, 44, 1528-1535.

20. Nour, V., Ionica, M. E., Trandafir, I. (2015). Bread enriched in lycopene and other bioactive compounds by addition of dry tomato waste. Journal of Food Science and Technology, 52, 8260-8267.
21. O'Shea, N., Arendt, E. K., Gallagher, E. 2012. Dietary fibre and phytochemical characteristics of fruit and vegetable by-products and their recent applications as novel ingredients in food products. Innovative Food Science and Emerging Technologies, 16, 1-10.

22. Pajin, B. (2009). Praktikum iz tehnologije konditorskih proizvoda, Tehnološki fakultet, Novi Sad.

23. Robertson, J.A., de Monredon, F.D., Dysseler, P., Guillon, F., Amado, R., Thibault, J.F. (2000). Hydration properties of dietary fibre and resistant starch: a European collaborative study. LWT-Food Science and Technology, 33, 72-79.

24. Soto-Vaca, A., Gutierrez, A., Losso, J.N., Xu, Z., Finley, J.W. (2012). Evolution of phenolic compounds from color and flavor problems to health benefits. Journal of Agricultural and Food Chemistry, 60, 6658-6677.

25. Yağcı, S., Göğüş, F. (2008). Response surface methodology for evaluation of physical and functional properties of extruded snack foods developed from food-by-products. Journal of Food Engineering, 86, 122-132.

\title{
УТИЦАЈ ДОДАТКА ТРОПА ПАРАДАЈЗА НА ФИЗИЧКЕ И СЕНЗОРСКЕ ОСОБИНЕ ЧАЈНОГ ПЕЦИВА ОД ИНТЕГРАЛНОГ РАЖАНОГ БРАШНА
}

\author{
Јелена М. Томић ${ }^{* 1}$, Миона М. Беловић ${ }^{1}$, Александра М. Торбица ${ }^{1}$, Биљана С. Пајин ${ }^{2}$, \\ Ивана С. Лончаревић ${ }^{2}$, Јована С. Петровић ${ }^{2}$, Александар М. Фиштеш ${ }^{2}$ \\ ${ }^{1}$ Универзитет у Новом Саду, Научни институт за прехрамбене технологије у Новом \\ Саду, 21000 Нови Сад, Булевар цара Лазара бр. 1, Србија \\ ${ }^{2}$ Универзитет у Новом Саду, Технолошки факултет, 21000 Нови Сад, Булевар цара \\ Лазара бр. 1, Србија
}

Сажетак: Троп парадајза као нуспроизвод прераде парадајза представља једну од потенцијалних сировина која може да се користи за израду прехрамбених производа са додатом нутритивном вредношћу. Са друге стране, захтеви потрошача за разноврсном храном са потенцијалним благотворним дејством на људско здравље намеће потребу за креирањем производа који укључују употребу различитих жита. Имајући то у виду, циљ овог рада је оцена утицаја додатка сушеног тропа парадајза на физичка и сензорска својства чајног пецива од интегралног ражаног брашна. Интегрално ражано брашно за чајно пециво је у стандардној формулацији теста за чајно пециво замењено тропом парадајза у два нивоа (15\% и 25\%). Квалитет готовог производа је оцењен инструменталним и сензорским методама. Резултати јасно показују да ниво тропа парадајза у формулацији чајног пецива повећава удео црвене $\left(+a^{*}\right)$ и жуте боје $\left(+\mathrm{b}^{*}\right)$, услед каротеноида присутних у тропу парадајза. Фактор ширења чајног пецива са додатком тропа парадајза у праху је већи у односу на контролни узорак. Тврдоћа чајног пецива са нивоом супституције од $25 \%$ је мања за око $50 \%$ у односу на контролни узорак. Према резултатима сензорске анализе, ниво супституције од 15\% проузроковао је снижење храпавости површине, ломљивости и зрнавости, као и повећање интензитета ароме карамела. Ниво супституције од $25 \%$ проузроковао је веће омекшање кекса и већу израженост ароме парадајза.

Кључне речи: троп парадајза, интегрално ражано брашно, чајно пециво, текстура, сензорска анализа 